\title{
Financing Constraints, Earnings Management and Corporate Tax Avoidance
}

\author{
Yiyang Yu \\ School of Economics and Management, Southwest Jiaotong University, Chengdu, China \\ 625694240@qq.com
}

\begin{abstract}
Based on the data of all A-share listed companies from 2008 to 2019, this paper studies the relationship between financing constraints and the degree of tax avoidance and the influencing path of them. The results show that financing constraints can promote enterprises to avoid tax aggressively. The results of heterogeneity test show that the difference of property rights and enterprise scale will not affect the above results. Further research shows that a high degree of earnings management will enhance the promotion of financing constraints on tax avoidance.
\end{abstract}

Keywords: Financing Constraints; Enterprise Tax Avoidance; Earnings Management.

\section{Introduction}

Hanlon (2005) defined corporate tax avoidance as reducing the taxes paid by enterprises. Usually, corporate tax avoidance can significantly increase the cash inflow of enterprises. Therefore, financing constraint has become a key factor affecting the degree of tax avoidance of enterprises. Financing constraint refers to the friction in the capital market, which causes enterprises to be unable to obtain external financing or the cost of external financing is too high, forcing enterprises to give up existing investment opportunities (Chen, 2018). Academic circles mainly discuss the influencing factors of financing constraints from two aspects: (1) Heng (2014), Farre-Mensa (2016) and other scholars found that the degree of financing constraints of enterprises is positively correlated with the degree of information asymmetry. (2) State-owned enterprises and non-state-owned enterprises face different financing constraints due to their different ability to obtain external resources (Zhang Yang, 2016).

Most enterprises will choose earnings management to improve their tax avoidance, thereby reducing cash outflow and alleviating financing constraints (Pi Xin, 2015). The existing literature on earnings management mainly focuses on motivation and means. (1) Healy et al. (1999) summarized the motivation of earnings management into three aspects: capital market motivation, contract motivation and supervision motivation. (2)Bernstein(1972), Liu (2015) and Cui (2015) think that enterprises will make use of non-recurring gains and losses, changes in accounting policies and accounting estimates for earnings management.

In this paper, all A-share non-financial listed companies from 2008 to 2019 are selected as the research objects, and the influence of financing constraints on the degree of tax avoidance and its influencing mechanism are investigated. The results show that the higher the degree of financing constraint, the more likely it is for enterprises to adopt aggressive tax avoidance strategies. Further mechanism research shows that a high degree of earnings management will strengthen the relationship between financing constraints and aggressive tax avoidance.

The possible marginal contributions of this paper are as follows: (1) This paper improves the research content of tax avoidance behavior, financing constraint and earnings management, and has certain reference value for the follow-up research of financing constraint, enterprise tax avoidance and earnings management; (2) From the perspective of earnings management, this paper further studies the new mechanism of financing constraints affecting tax avoidance, which is a useful supplement to the existing research. 


\section{Research Hypothesis}

Because of the information asymmetry and transaction cost in the real capital market, the cost of obtaining funds from outside is higher than that from inside, so the problem of financing constraint is widespread. For enterprises facing financing constraints, the quickest way to get out of the predicament is to increase their cash and reduce their cash expenditure. However, corporate tax avoidance can reduce the tax burden and cash expenditure of enterprises, which is essentially equivalent to corporate financing (Ye and Liu, 2014), and can alleviate the dilemma of financing constraints. Whether an enterprise avoids tax or not depends on the trade-off between the value and cost of tax avoidance. The measures taken by enterprises for reasonable tax avoidance will increase the cost of enterprises, but on the other hand, reasonable tax avoidance can effectively reduce the cash expenditure of enterprises, thus alleviating the financing constraint dilemma of enterprises. Therefore, enterprises that have been deeply mired in the financing constraint dilemma may have no time to consider the disadvantages brought by enterprise tax avoidance and choose to accept the benefits brought by enterprise tax avoidance. Therefore, when the financing constraint degree of enterprises is high, in order to grasp the favorable investment opportunities, enterprises with financing constraints may be forced to choose radical tax avoidance measures to replace the foreign financing with excessive cost. Based on the above analysis, we propose hypothesis 1:

Hypothesis 1: Financing constraints will induce radical tax avoidance, that is, the higher the degree of financing constraints, the more radical the tax avoidance of enterprises.

\section{Research Design}

\subsection{Sample Selection and Data Sources}

In this paper, all A-share listed companies from 2008 to 2019 are selected as research samples, and the samples are selected according to the following criteria: (1) In order to avoid the influence of outliers, this paper excludes the enterprise samples of ST, *ST and PT companies; (2) Excluding financial listed companies; (3) Eliminate samples with incomplete data and abnormal data; (4) 1\% tail reduction (Winsor) is applied to all continuous variables.

\subsection{Variable Design}

\subsubsection{Measurement of Tax Avoidance Degree of Enterprises}

According to the practices of Liu \& $\mathrm{Wu}(2014)$ and Xie, etc. (2016), this paper measures the tax avoidance degree of enterprises by using the actual income tax rate (TR) calculated by the formula. The higher the calculated actual income tax rate, the higher the negative enterprise income tax, and the lower the tax avoidance degree. The calculation method of actual income tax rate is shown in Formula (1).

$$
\text { Actual income tax rate }(T R)=\frac{\text { Income tax expense- } \text { deferred income tax expense }}{\text { the total profit-Deferred income tax expense } / \text { Nominal income tax rate }}
$$

\subsubsection{Measurement of Financing Constraint Degree}

The measurement of financing constraint refers to the practices of Hadlock \& Pierce (2010) and Deng Kebin (2017), and measures the degree of financing constraint of enterprises by SA index. size $\mathrm{i}_{\mathrm{i}, \mathrm{t}}$ is the scale of enterprises, and Age $e_{i, t}$ is the age of enterprises. The calculated SA index is negative. For convenience of comparison, this paper takes the absolute value of SA index, and the greater the absolute value, the more serious the financing constraint. The specific calculation method is as follows:

$$
S A_{i, t}=-0.737 \text { size }_{i, t}+0.043 \text { size }_{i, t}{ }^{2}-0.04 A g e_{i, t}
$$


Specific variable definitions are shown in Table 1.

Table 1. Variable Definition Table

\begin{tabular}{|c|c|c|c|}
\hline Variable type & Variable name & $\begin{array}{c}\text { variable } \\
\text { symbol }\end{array}$ & Variable definition \\
\hline $\begin{array}{c}\text { Interpreted } \\
\text { variable }\end{array}$ & Tax avoidance degree & TR & The calculation method is detailed above \\
\hline $\begin{array}{l}\text { Explanatory } \\
\text { variable }\end{array}$ & Financing constraint & SA & The calculation method is detailed above \\
\hline \multirow{8}{*}{ Control variable } & Scale & Size & $\begin{array}{c}\text { Natural logarithm of total assets at the end of } \\
\text { the year }\end{array}$ \\
\hline & $\begin{array}{l}\text { Intensity of fixed } \\
\text { assets }\end{array}$ & Cap & Net fixed assets/total assets \\
\hline & $\begin{array}{l}\text { Intensity of intangible } \\
\text { assets }\end{array}$ & Int & Net intangible assets / total assets \\
\hline & Inventory density & Inv & Years of listing \\
\hline & Period cost rate & Sale & Period expenses / operating income \\
\hline & $\begin{array}{c}\text { Executive } \\
\text { compensation }\end{array}$ & Comp & $\begin{array}{c}\text { Natural logarithm of the top three executive } \\
\text { compensation totals }\end{array}$ \\
\hline & year & Year & Annual dummy variable \\
\hline & industry & Ind & Industry dummy variable \\
\hline
\end{tabular}

\subsection{Model Construction}

In order to verify the hypothesis, this paper constructs the model (3)

$$
\begin{aligned}
T R_{i, t}= & \alpha_{0}+\alpha_{1} S_{i, t}+\alpha_{2} \text { Size }_{i, t}+\alpha_{3} \operatorname{Cap}_{i, t}+\alpha_{4} \operatorname{Int}_{i, t}+\alpha_{5} \operatorname{Inv}_{i, t}+\alpha_{6} \text { Sale }_{i, t}+ \\
& \alpha_{7} \operatorname{Comp}_{i, t}+\sum \text { Year }+\sum \text { Ind }+\varepsilon_{i, t}
\end{aligned}
$$

Among them, $\alpha_{\mathrm{i}, \mathrm{t}}$ is the intercept term, $\alpha_{1}$ is the estimation coefficient of the explanatory variable, $\alpha_{2} \sim \alpha_{71}$ is the estimation coefficient of the control variable, and $\varepsilon$ (M26) is the residual term.

\section{Empirical Results and Analysis}

\subsection{Descriptive Statistics}

Table 2 shows the sample descriptive statistical results of the main variables. The index Sa of financing constraints is between $2.767 \sim 4.116$, with an average of 3.568 and a median of 3. 555.The index tr for measuring the degree of tax avoidance is $0.015 \sim 0.747$, with an average of 0.197 and a median of 0.175 , indicating that the actual tax rate of Listed Companies in the sample is less than the statutory tax rate, which preliminarily proves the existence of corporate tax avoidance.

Table 2. Descriptive Statistical Results

\begin{tabular}{|c|c|c|c|c|c|c|}
\hline variable & $\begin{array}{c}\text { sample } \\
\text { size }\end{array}$ & $\begin{array}{c}\text { mean } \\
\text { value }\end{array}$ & $\begin{array}{c}\text { 50th } \\
\text { percentile }\end{array}$ & $\begin{array}{c}\text { minimum } \\
\text { value }\end{array}$ & Maximum & $\begin{array}{c}\text { standard } \\
\text { deviation }\end{array}$ \\
\hline TR & 7673 & 0.197 & 0.175 & 0.015 & 0.747 & 0.110 \\
\hline SA & 7673 & 3.568 & 3.555 & 2.767 & 4.116 & 0.269 \\
\hline size & 7673 & 8.968 & 8.750 & 6.600 & 13.030 & 1.339 \\
\hline Cap & 7673 & 0.219 & 0.183 & 0.003 & 0.698 & 0.162 \\
\hline
\end{tabular}

\subsection{Correlation Analysis}

Table 3 shows the relationship between the degree of tax avoidance and the financing constraints and control variables. It can be seen from table 3 that TR and SA are significantly positively correlated 
at the $1 \%$ level, which indicates that the higher the degree of financing constraints, the higher the degree of corporate tax avoidance, which preliminarily confirms hypothesis 1 .

Table 3. Correlation Coefficient

\begin{tabular}{|c|c|c|c|c|c|c|c|c|}
\hline variable & TR & SA & size & Cap & Int & Inv & Comp & sale \\
\hline TR & 1 & & & & & & & \\
\hline SA & $0.102^{* * *}$ & 1 & & & & & & \\
\hline size & $0.155^{* * *}$ & $-0.102^{* * *}$ & 1 & & & & & \\
\hline Cap & 0.015 & $-0.066^{* * *}$ & $0.065^{* * *}$ & 1 & & & & \\
\hline Int & $0.042^{* * *}$ & $-0.455^{* * *}$ & $-0.023^{* * *}$ & $0.118^{* * *}$ & 1 & & & \\
\hline Inv & $0.197^{* * *}$ & $0.096^{* * *}$ & $0.138^{* * *}$ & $-0.430^{* * *}$ & $-0.276^{* * *}$ & 1 & & \\
\hline Comp & $0.036^{* * *}$ & $0.050^{* * *}$ & $0.456^{* * *}$ & $-0.108^{* * *}$ & $-0.077^{* * *}$ & $0.103^{* * *}$ & 1 & \\
\hline sale & $-0.132^{* * *}$ & -0.009 & $-0.277^{* * *}$ & $-0.085^{* * *}$ & $0.096^{* * *}$ & $-0.196^{* * *}$ & 0.017 & 1 \\
\hline
\end{tabular}

Note: $* * *, * *, *$ represent significance levels of $1 \%, 5 \%$ and $10 \%$ respectively.

\subsection{Financing Constraints and Corporate Tax Avoidance}

Table 4 shows the regression results of corporate tax avoidance on financing constraints. The coefficient of SA is -0.058 , and the value of $\mathrm{T}$ is -2.43 , which is significantly negative at the level of $1 \%$. It shows that the higher the degree of financing constraint, the lower the actual income tax rate of enterprises, and the higher the degree of tax avoidance of enterprises. Hypothesis 1 is verified.

Table 4. Financing Constraints and Corporate Tax Avoidance

\begin{tabular}{|c|c|}
\hline variable & TR \\
\hline $\mathrm{SA}$ & $-0.058^{* * *}$ \\
$(-2.43)$ \\
\hline $\mathrm{N}$ & 7673 \\
\hline industry & control \\
\hline year & control \\
\hline within $\mathrm{R}^{2}$ & 0.013 \\
\hline
\end{tabular}

*The significance levels of $1 \%, 5 \%$ and $10 \%$ are respectively represented by the following three methods: (1), (5\%) and (10\%) respectively. The robust standard error is used for all regression, and the data in brackets is the standard error.

\subsection{Robustness Test}

\subsubsection{Endogenous Problems}

In the process of regression, we should pay attention to the endogenous problem of financing constraints, that is, the degree of tax avoidance of enterprises may have a reverse effect on financing constraints. Therefore, referring to the practice of Chen and Fang (2018), this paper introduces the financing constraint variable (LSA) with one lag period and the financing constraint variable with two lag periods (lsa2) into the regression of model (3), so as to minimize the endogenous problem between financing constraints and the degree of corporate tax avoidance.

Column (1) of table 5 reports the regression results of LSA replacing SA as an independent variable in formula (3). The estimated coefficient of LSA is -0.07 , which is significantly negative at the level of $1 \%$. It indicates that the stronger the financing constraints, the lower the actual income tax rate and the higher the degree of tax avoidance. Hypothesis 1 is verified. Column (2) reports the regression results of lsa2 instead of SA as independent variable in formula (3). The coefficient of 1sa2 is -0.088 , which is significantly negative at the level of $5 \%$. The regression results show that the higher the financing constraints, the higher the degree of tax avoidance of enterprises, which further verifies the reliability of the results of this paper.

\subsubsection{Alternative Variables}

(1) In the robustness test, this paper also uses WW index as the financing constraint proxy variable of SA index, because WW index not only considers the financial characteristics of the enterprise itself, 
but also considers the external environment characteristics of the enterprise, which makes it have more extensive economic significance. The WW index is calculated as follows:

$$
\begin{gathered}
W W_{i, t}=-0.091 C F_{i, t}-0.062 \operatorname{DivPos}_{i, t}+0.021 L E V_{i, t}-0.044 \operatorname{size}_{i, t}+0.102 I S G_{i, t}- \\
0.035 S G_{i, t}
\end{gathered}
$$

Using WW index as a substitute variable of financing constraints, regression equation (3) is carried out. The larger the WW index, the higher the degree of financing constraints. It can be seen from column (3) of table 5 that the coefficient of WW index is -0.136 , which is significantly negative at the level of $5 \%$, indicating that the positive correlation between financing constraints and tax avoidance degree is robust and reliable, and hypothesis 1 is verified.

(2) In the robustness test, the accounting tax difference is used to measure the Tax Avoidance Index TA, which is represented by BTD. In the model (3), the greater the accounting difference BTD, the greater the degree of tax avoidance. The regression results are shown in column (4) of table 5. The coefficient of SA is 0.002 , which is significantly positive at the $10 \%$ level. Hypothesis 1 is verified again.

\begin{tabular}{|c|c|c|c|c|}
\hline & (1) & (2) & (3) & (4) \\
\hline variable & TR & TR & TR & BTD \\
\hline LSA & $\begin{array}{c}-0.070 * * * \\
(-2.60)\end{array}$ & & & \\
\hline LSA2 & & $\begin{array}{c}-0.088^{* *} \\
(-2.37) \\
\end{array}$ & & \\
\hline WW & & & $\begin{array}{c}-0.136 * * \\
(-2.20) \\
\end{array}$ & \\
\hline SA & & & & $\begin{array}{l}0.002 * \\
(0.22)\end{array}$ \\
\hline $\mathrm{N}$ & 5418 & 4116 & 6826 & 7673 \\
\hline industry & control & control & control & control \\
\hline year & control & control & control & control \\
\hline within $R^{2}$ & 0.015 & 0.022 & 0.016 & 0.111 \\
\hline
\end{tabular}

Table 5. Robustness Test

\subsection{Heterogeneity Test}

\subsubsection{Property Right Nature}

Due to the different system characteristics in China, the degree of tax avoidance of enterprises may show different characteristics due to different property rights, which may have an impact on the above results. Therefore, this paper takes the nature of property rights into the research framework of financing constraints and corporate tax avoidance behavior, and tests whether the relationship between them will change under different property rights.

According to columns (1) - (2) of table 6, the coefficient of SA in the subsample of non-stateowned enterprises is not significant, but it is negative, which is in line with the expectation; in the subsample of state-owned enterprises, the coefficient of SA is -0.078 , which is significantly negative at the level of $1 \%$, which is in line with the expected results. The results show that the positive correlation between financing constraints and the degree of corporate tax avoidance does not have significant differences due to the nature of property rights.

\subsubsection{Enterprise Scale}

There are great differences in financing constraints among enterprises of different sizes. Due to the imperfect financial market and asymmetric information, it is difficult for lenders to judge whether SMEs have enough ability to repay loans. Therefore, compared with large enterprises, SMEs may 
choose radical tax avoidance to alleviate their own financing constraints (Zhang Xuan, 2017). Therefore, in order to verify the impact of enterprise size on the degree of enterprise tax avoidance, this paper divides the total sample into large and medium-sized enterprises according to the median of enterprise size.

Columns (3) - (4) in Table 6 report the estimated results of enterprises of different sizes. In the regression results of large enterprises, the SA index is significantly negative at the level of $5 \%$, and the SA index of small and medium enterprises is significantly negative at the level of $10 \%$. The results show that the relationship between financing constraints and corporate tax avoidance does not change significantly with the size of enterprises.

Table 6. Heterogeneity Test

\begin{tabular}{|c|c|c|c|c|}
\hline & $(1)$ & $(2)$ & $(3)$ & $(4)$ \\
\hline \multirow{2}{*}{ variable } & $\begin{array}{c}\text { state-owned } \\
\text { enterprise }\end{array}$ & $\begin{array}{c}\text { Non state-owned } \\
\text { enterprises }\end{array}$ & $\begin{array}{c}\text { Large } \\
\text { enterprises }\end{array}$ & $\begin{array}{c}\text { Small and medium } \\
\text { enterprises }\end{array}$ \\
\hline \multirow{2}{*}{ SA } & $-0.078^{* * *}$ & -0.006 & $-0.001^{* *}$ & $-0.263^{*}$ \\
& $(-2.15)$ & $(-0.16)$ & $(-0.03)$ & $3.50)$ \\
\hline $\mathrm{N}$ & 3863 & 3647 & 3837 & 3836 \\
\hline industry & control & control & control & control \\
\hline year & control & control & control & control \\
\hline within $\mathrm{R}^{2}$ & 0.020 & 0.002 & 0.032 & 0.004 \\
\hline
\end{tabular}

\section{Mechanism Analysis}

\subsection{The Impact of Earnings Management on Corporate Tax Avoidance}

\subsubsection{Variable Design}

When an enterprise falls into the dilemma of financing constraints, it will use earnings management to increase the information content of accounting earnings, so as to alleviate the financing constraints of enterprises (Chen Shen, 2020). Therefore, easing financing constraints is one of the main factors for enterprises to manage earnings. Earnings management refers to the behavior that enterprises manipulate the accounting earnings information provided to the outside world by changing accounting policies, accounting estimates and using non-recurring gains and losses on the basis of complying with relevant laws and regulations (Ning, 2004). In addition, studies at home and abroad show that tax burden is an important reason for enterprises to implement earnings management. When corporate tax burden is too high, large multinational companies will delay the recognition of current earnings to reduce corporate current tax burden (Guidry,1999), or enterprises may tend to reduce corporate tax burden through tax planning (Xia, 2019). Enterprises trapped in financing constraints will strengthen their tax avoidance behavior in order to increase their cash holdings and reduce their cash expenditures. At this time, enterprises often use earnings management to improve the degree of tax avoidance. Therefore, this paper puts forward hypothesis 2 :

Hypothesis 2: A high degree of earnings management will strengthen the relationship between financing constraints and aggressive tax avoidance.

\subsubsection{Model Selection}

(1) Accrued Earnings Management

This paper uses the research of Lei \& Liu (2006), Wang (2015) and Dong (2020) for reference, and uses the modified Jones model to measure the accrued earnings management variables in this paper.

The calculation formula is as follows:

$$
\frac{T A_{i t}}{A_{i t-1}}=\alpha_{1} \frac{1}{A_{i t-1}}+\alpha_{2} \frac{\Delta R E V_{i t}}{A_{i t-1}}+\alpha_{3} \frac{P P E_{i t}}{A_{i t-1}}+\varepsilon_{i t}
$$


Volume 15 (2021)

$$
\begin{gathered}
N D A_{i t}=\alpha_{1} \frac{1}{A_{i t-1}}+\alpha_{2}\left(\frac{\Delta R E V_{i t}}{A_{i t-1}}-\frac{\Delta R E C_{i t}}{A_{i t-1}}\right)+\alpha_{3} \frac{P P E_{i t}}{A_{i t-1}} \\
D A_{i t}=\frac{T A_{i t}}{A_{i t-1}}-N D A_{i t}
\end{gathered}
$$

$\mathrm{DA}_{\mathrm{i}, \mathrm{t}}$ is the manipulative accruals in the $\mathrm{t}$ period. Since the manipulative accruals have a signed direction, this paper uses the absolute value of the manipulative accruals (ABSDA) to measure the level of accrued earnings management. The greater the absolute value of ABSDA, the greater the degree of earnings management.

(2) Real Earnings Management

Real Earnings Management (REM) This paper follows RoyChowdhury (2006) model, and constructs a model from three aspects: abnormal production cost (DPROD), abnormal cash flow from operating activities (DCFO) and abnormal discretionary expenses (DDISEXP), and obtains comprehensive indicators to measure the company's real earnings management. The formula is as follows:

$$
\begin{aligned}
& \frac{\mathrm{CFO}_{i, t}}{A_{i, t-1}}=\alpha_{0}+\alpha_{1} \frac{1}{A_{i, t-1}}+\alpha_{2} \frac{\operatorname{SALES}_{i, t}}{A_{i, t-1}}+\alpha_{3} \frac{\Delta \text { SALES }_{i, t}}{A_{i, t-1}}+\varepsilon_{i, t} \\
& \frac{\operatorname{PROD}_{i, t}}{A_{i, t-1}}=\alpha_{0}+\alpha_{1} \frac{1}{A_{i, t-1}}+\alpha_{2} \frac{\operatorname{SALES}_{i, t}}{A_{i, t-1}}+\alpha_{3} \frac{\Delta \text { SALES }_{i, t}}{A_{i, t-1}}+\alpha_{4} \frac{\Delta S A L E S_{i, t-1}}{A_{i, t-1}}+\varepsilon_{i, t} \\
& \frac{D I S E X P}{A_{i, t-1}}=\alpha_{0}+\alpha_{1} \frac{1}{A_{i, t-1}}+\alpha \frac{\operatorname{SALES}_{i, t-1}}{A_{i, t-1}}+\varepsilon_{i, t} \\
& R E M_{i, t}=D P R O D_{i, t}-D D I S E X P_{i, t}-D C F O_{i, t}
\end{aligned}
$$

The calculated REM has a symbolic direction, but both of them will have an impact on business risks. Therefore, this paper uses the absolute value of real earnings management (ABSREM) to measure the real earnings management level. The greater the absolute value of ABEREM, the greater the degree of earnings management.

To verify the hypothesis, this paper constructs a model (12)

$$
\begin{gathered}
T R_{i, t}=\beta_{0}+\beta_{1} S A_{i, t}+\beta_{2} S A_{i, t} \times A B S D A_{i, t}+\beta_{3} A B S D A_{i, t}+\beta_{4} \text { Size }_{i, t}+\beta_{5} \text { Cap }_{i, t}+\beta_{6} \text { Int }_{i, t}+ \\
\beta_{7} \operatorname{Inv}_{i, t}+\beta_{8} \text { Sale }_{i, t}+\beta_{9} \operatorname{Comp}_{i, t}+\sum \text { Year }+\sum \text { Ind }+\varphi_{i, t}
\end{gathered}
$$

Among them, $\beta_{2}$ is intercept term, $\beta_{1} \sim \beta_{3}$ is estimation coefficient of explanatory variable, $\beta_{4} \sim \beta_{9 i s}$ estimation coefficient of control variable, and $\varphi \mathrm{i}, \mathrm{t}$ is residual term.

Column (1) of table 7 gives the multiple regression results of model (11). The regression results show that the coefficient of SA $\times$ ABSDA is significantly negative at the level of $5 \%$. It shows that when faced with financing constraints, compared with companies with lower accrued earnings management, companies with higher accrued earnings management have a slightly higher degree of tax avoidance. Hypothesis 2 is verified. For the robustness of the results, this paper takes authentic earnings management as an alternative variable, and puts it into the regression model instead of accrued earnings management for testing. The test results are shown in the second column of Table 7. The result shows that the coefficient of $S A \times A B S R E M$ is -0.020 , which is significantly negative at the level of $10 \%$. the hypothesis is verified again, which shows that the result is robust and reliable. 
Table 7. Mechanism Analysis

\begin{tabular}{|c|c|c|}
\hline & $(1)$ & $(2)$ \\
\hline variable & Accrued earnings management & Real earnings management \\
\hline \multirow{2}{*}{ SA } & $-0.055^{* *}$ & $-0.057^{* *}$ \\
& $(-2.34)$ & $(-2.38)$ \\
\hline \multirow{2}{*}{ ABSDA } & $-0.074^{* * *}$ & \\
& $(-3.72)$ & \\
\hline \multirow{2}{*}{ SA·ABSDA } & $-0.149^{* *}$ & $(-2.03)$ \\
\hline \multirow{2}{*}{ ABSREM } & & $-0.018^{*}$ \\
& & $(-1.75)$ \\
\hline \multirow{2}{*}{ SA·ABSREM } & & $-0.020^{*}$ \\
& & $(-0.48)$ \\
\hline $\mathrm{N}$ & 7673 & 7673 \\
\hline industry & control & control \\
\hline year & control & control \\
\hline within $\mathrm{R}^{2}$ & 0.0156 & 0.0133 \\
\hline
\end{tabular}

\section{Conclusions and Suggestions}

Based on the financial data from 2008 to 2019, this paper analyzes the influence of financing constraints on the tax avoidance degree of enterprises from the micro-perspective of enterprises. The empirical test results show that the higher the financing constraints, the higher the tax avoidance degree of enterprises. Based on this, this paper studies the influence of a high degree of earnings management on the relationship between financing constraints and corporate tax avoidance. The research shows that the stronger the financing constraints faced by enterprises, the more likely they are to choose radical tax avoidance methods, thus improving the tax avoidance degree of enterprises. After a series of robustness tests, this conclusion is still valid. Further mechanism research shows that a high degree of earnings management will strengthen the relationship between financing constraints and the degree of tax avoidance. The above conclusions will not be affected by the property rights of enterprises.

The results of this study show that when facing with favorable investment opportunities, enterprises with financing constraints will adopt aggressive tax avoidance strategies to alleviate the dilemma under financing constraints. However, radical tax avoidance measures have greatly reduced the tax burden borne by enterprises and caused the loss of national tax revenue. Therefore, tax avoidance is not an appropriate way to solve financing constraints. Therefore, in order to solve the current situation that the higher the degree of financing constraints and the higher the degree of tax avoidance of enterprises, we must firstly create a fair, reasonable and effective financing environment for enterprises; Secondly, the state should improve the efficiency of tax law implementation and strengthen tax collection and management; Finally, when formulating accounting standards and accounting systems, we should strengthen the construction of relevant standards for non-taxable items, improve the financial reporting requirements, and reduce the operating space of earnings management.

\section{References}

[1] Badertscher B A, Katz S P, Rego S O. The Separation of Ownership and Controland Corporate Tax Avoidance [J] Journal of Accounting and Economics, 2013,56(2):228-250.

[2] Cheng B, Ioannou I, Serafeim G. Corporate Social Responsibility and Access to Finance[J] Strategic Management Journal, 2014,35(1):1-23.

[3] Desai M, Dharmapala D. Corporate Tax Avoidance and High-powered Incentives [J] Journal of Financial Economics,2006,79(1):145-179.

[4] Farre-Mensa J, Ljungqvist A. Do Measures of Financial Constraints Measure Financial Constraints?[J] Review of Financial Studies,2016,29(2):271-308. 
[5] Graham J, M Hanlon, T Shevlin, and N Shroff.Incentives for Tax Planning and Avoidance: Evidence from The Field [J] The Accounting Review,2014,89(3):991-1023.

[6] Hanlon, M., Heitzman, S. A Review of Tax Research. [J]Journal of Accounting and Economics, 2010, 50 (2): $127-178$.

[7] Bao C. Literature Review of Earnings Management [J] Economic Research Guide, 2016(14):126-127.

[8] Cui S. Analysis of Accounting Estimation Change and Earnings Management [J] Contemporary Accounting, 2015(09):70-72.

[9] Chen Z., \& Fang H. Financing Constraint, Internal Control and Enterprise Tax Avoidance [J] Management Science, 2018,31(03):125-139.

[10] Chen Z., \& Fang H. corporate tax avoidance behavior and investor system risk estimation [J] Journal of Management Science, 2016,29(05):134-146.

[11] Chen J. Tax Collection and Management, Internal Control Quality and Corporate Tax Avoidance [J] Taxation and Economy, 2014(06):68-75.

[12] Dong Y., Ding B., \& Liu Y. Analysis of Information Disclosure of Non-recurring Gains and Losses of Listed Companies-based on the 2012 Annual Report of Automobile Industry [J] Communication of Finance and Accounting, 2015(28):29-33.

[13] Dai B., Peng C., \& Liu X. Management Ability, Power and Corporate Tax Avoidance Behavior [J] Finance \& Trade Economics, 2016(04):43-57.

[14] Du W. Voluntary Accounting Policy Change, Real Earnings Management and Audit Opinion Deviation [J] Communication of Finance and Accounting, 2021(01):41-45. 